\title{
Two interesting ostracod species from Montenegro (SE Europe)
}

\author{
I. Karanovic ${ }^{1}$ \\ T. K. Petkovski ${ }^{2}$
}

Keywords : taxonomy, Ostracoda, Cytheracea, Montenegro, Skadar Lake.

Two species of superfamily Cytheracea from Skadar Valley (Montenegro), are presented in this paper. Leptocythere pseudoproboscidea n.sp., collected in a spring is very close to Leptocythere proboscidea Klie, 1939, an endemic species of the Ohrid Lake. Paralimnocythere karamani (Petkovski, 1960) occurred in two localities : river and spring. Until now, this species was considered endemic in the Ohrid-Prespa region. Its known distribution is non extended westwards and its presence in Skadar Valley confirms exchanges between faunas of Ohrid and Skadar drainage areas.

\section{Deux espèces intéressantes d'ostracodes du Monténégro (SE Europe)}

Mots-clés : taxonomie, Ostracoda, Cytheracea, Monténégro, Lac Skadar.

Deux espèces de la super-famille des Cytheracea de la Vallée de Skadar (Montenegro) sont présentées. Leptocythere pseudoproboscidea n.sp. espèce récoltée dans une source, est remarquablement proche de l'espèce endémique du Lac Ohrid, Leptocythere proboscidea Klie, 1939. Paralimnocythere karamani (Petkovski, 1960) a été récoltée dans deux localités : une rivière et une source. Elle était considérée comme une espèce endémique de la région Ohrid-Prespa. Aujourd'hui, sa répartition semble plus large et sa présence dans la Vallée de Skadar confirme les échanges faunistiques entre le Lac Ohrid et le Lac Skadar.

\section{Introduction}

The Ostracod fauna of Montenegro is poorly known and it has never been investigated systematically. The first data were given by Klie (1936) when he described two new species : Candona bimucronata Klie, 1936 and Cypridopsis clathrata Klie, 1936. Petkovski (1961) described two new species from Skadar Lake : Candona montenegrina Petkovski, 1961 and Limnocythere scutariense Petkovski, 1961. In the same paper Petkovski gave data for seven other ostracod species collected in Skadar Lake : Ilyocypris gibba (Ramdohr, 1808), Candona cf. paionica Petkovski, 1959, Cypria lacustris Sars, 1890, Physocypria kerkyrensis Klie, 1936, Cypridopsis vidua (O. F. Muller, 1776), Potamocypris variegata (Brady \& Norman, 1889) and Darwi-

1. Institute of Marine Biology, P.O. Box 69, 85335 Kotor, Montenegro, Yugoslavia.

2. Macedonian Museum of Natural History, Bulevar Ilinden 86, 91000 Skopje 55, Macedonia. nula stevensoni (Brady \& Robertson, 1889). With the except of those eleven species, seven other species (Petkovski 1960, 1964, 1976) are also known from Montenegro : Candona cf. strumice Petkovski, 1950, Cyclocypris ovum (Jurine, 1820), Cypria reptans stigia Klie, 1935, Psychrodromus fontinalis Wolf, 1920, Potamocypris steueri Klie, 1935, Potamocypris zschokkei Kaufmann, 1900 and Potamocypris wolfi Brehm, 1920.

Recently, two new species are also described from Skadar Valley (Karanovic \& Petkovski, in press) : Pseudocandona regisnikolai Karanovic \& Petkovski and Candonopsis mareza Karanovic \& Petkovski. In the present paper we describe one new species Leptocythere pseudoproboscidea n.sp., and redescribe Paralimnocythere karamani (Petkovski 1960), so the ostracod fauna of Montenegro now counts 22 species.

Paralimnocythere karamani is described from Ohrid Lake, and latter found also in Prespa Lake (Petkovski 1960a). Its finding in Skadar Valley enlarges the area of the species to the west. Also, this is a direct proof that faunas of Ohrid Lake and Skadar Valley commu- 
nicate trough the link Ohrid-Drim-Skadar. Species like Paralimnocythere karamani that was found in ecologically different localities (spring, lake, river) easily distributes by, above mentioned, link. Further investigation of Skadar Valley might show that some other species considered endemic in the Ohrid-Prespa region are also representatives of the ostracod fauna of Skadar Valley. The other species herein described, Leptocythere pseudoproboscidea $\mathrm{n}$. sp., is very similar to $L$. proboscidea Klie, 1939, an Ohrid endemic species.

In the present paper, except detail description and redescription of the two species, we give detail zoogeographic analysis of the ostracod faunas of Ohrid and Prespa Lake and Skadar Valley, the percent of endemic species in two Macedonian lakes, and we explain the importance of Skadar Valley as refugial center during cyclic periods of the Ice Ages.

\section{Methods}

Samples were taken with plankton net of $0.05 \mathrm{~mm}$ mesh size. Material is fixed with several drops of $36 \%$ formaldehyde. Specimens were separated with stereomicroscopes Wild-M5 in $70 \%$ ethyl-alcohol. Dissected specimens are studied and drawn by binocular microscope Wild-M20 and Leica DMLS with drawingtube. Examined material is preserved on slides in Faure's medium, and in glass test-tube in $70 \%$ ethyl-alcohol.

Terminology of the hemipenis is used according to Martens (1990).

Abbreviations used in text and figures : cp - copulatory process on hemipenis ; $\mathrm{dl} 1$ and $\mathrm{dl} 3$ - distal lobes on hemipenis ; $\mathrm{f}(1-3)$ - furcal setae ; $\mathrm{A} 1$ - antennula ; A2 - antenna ; Md palp - mandibular palp ; Mx - maxillula ; P (1-3) - walking legs.

\section{Site description}

Material was collected during the investigation of Ostracod fauna of Skadar Valley, and its, the most noticeable hydrological object, Skadar Lake. Drainage area of this Balkan lake is about $5500 \mathrm{~km}^{2}$ (Radulovic 1983), and is the richest drainage area in Montenegro. It is composed of underground and surface water flows, that are all connected, as it is the case in other karstic areas. Water from Skadar Valley drainage to Skadar Lake and then by Bojana river flow to Adriatic Sea. Bojana river is, also, indirect connection between Skadar and Ohrid lakes (Fig. 27). From Ohrid Lake flows out river Crni Drim and after connecting with river Beli Drim makes river Drim which empties into river Bojana on the Albanian territory. When water le- vels of river Bojana and Skadar Lake are lower than water level in Drim, then one part of Drim water directly flows to Skadar Lake, while other part by Bojana flows to Adriatic Sea (Radulovic 1983). This is the way through which faunas of Skadar and Ohrid drainage areas directly communicate.

\section{Results}

\subsection{Leptocythere pseudoproboscidea n.sp.}

(Figs 1-19)

\section{Etymology}

Leptocythere pseudoproboscidea is named after the most similar species Leptocythere proboscidea Klie, 1939, with latin prefix pseudo.

\section{Examined material}

1) Holotype (male $0.48 \mathrm{~mm}$ ), allotype (female $0.52 \mathrm{~mm}$ ) and six paratypes ( 1 male, 4 females and 1 juvenile) from spring Mareza, near town Podgorica, Skadar Valley, 08 December 1997, collector I. Karanovic.

2) Three females and two males from the same locality, 25 October 1994, collector I. Karanovic.

Holotype, allotype and five paratypes ( 3 males and 2 females) are dissected and with other specimens deposited in the private collection of the first author, at the Institute of Marine Biology Kotor, Montenegro.

\section{Description}

\section{MALE (Holotype)}

Carapace (Figs 1-3). Left valve $0.48 \mathrm{~mm}$, right valve $0.44 \mathrm{~mm}$ long. The greatest height situated on the first third of the length, equals $52 \%$ of the length, on the left, and $48.9 \%$ on the right valve. Seeing from above, the greatest width lies on the first third of the length, equals $33.3 \%$ of the length. Posterior end quadriform, anterior beaked. Dorsal margin straight and inclined at the posterior end with one settling on the first third of the left, and on the last third of the right valve. Anterior margin wider than posterior. Ventral margin convex around the mid-length. Line of concretion wide, with few branched pore canals on the anterior end. Valve surface sculptured, covered with sparse hairs. Color yellow-brown.

A1 (Fig. 10). Terminal segment 4.3 times as long as width. Sensory seta equals half the length of terminal seta. Terminal segment equals $50 \%$ of the length of distal claw on penultimate segment. Length ratio of both (proximal and distal) pairs of claws on penultimate segment $100: 50$. Setae on the same segment of about the same length. Claw on the third segment reaches till distal third of penultimate segment, while 


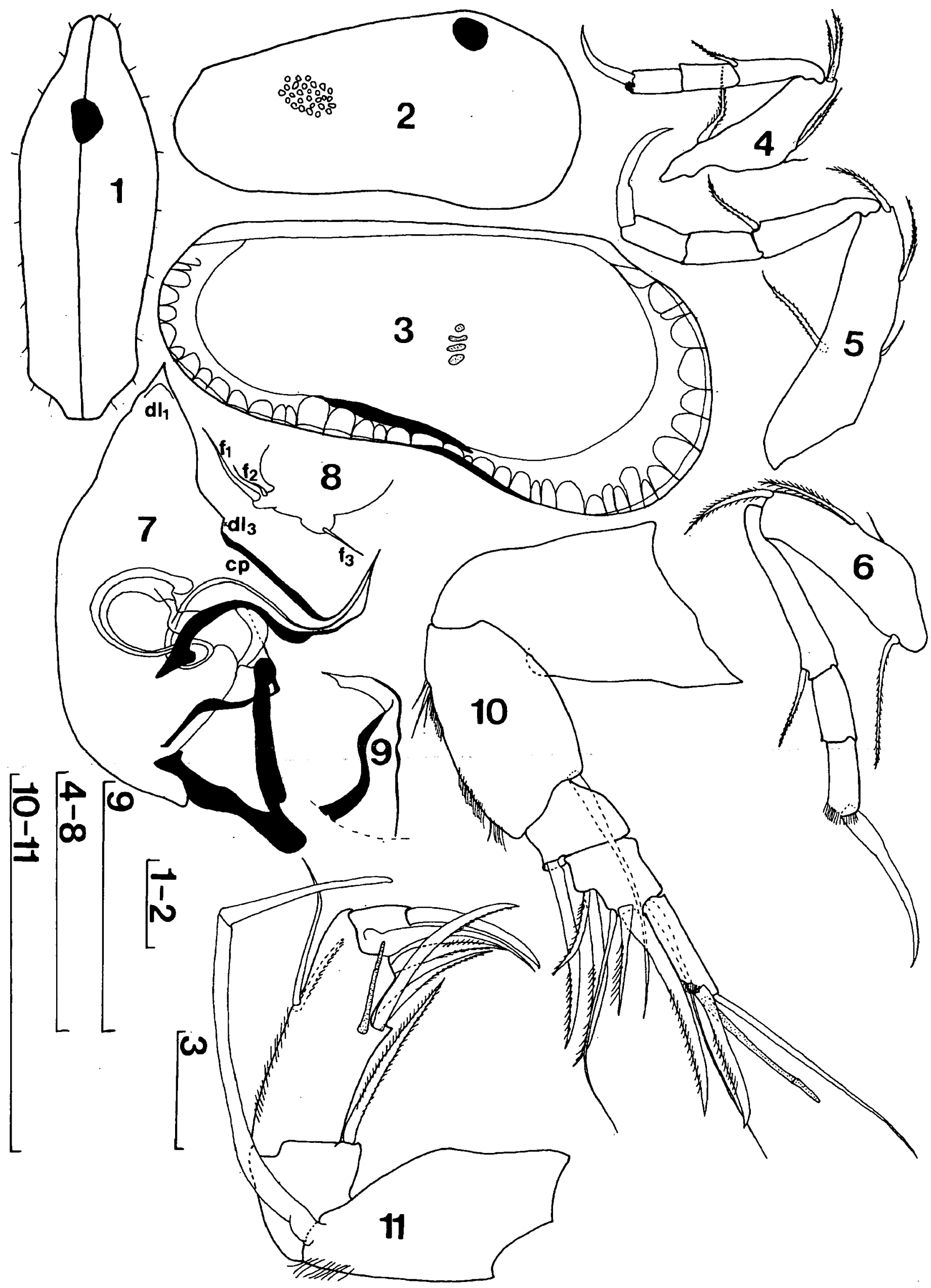

Figs. 1-11. Leptocythere pseudoproboscidea n.sp., holotype (male $0.48 \mathrm{~mm}$ ). 1 : dorsal view, 2 : right valve, $3:$ left valve, $4: \mathrm{P} 1,5: \mathrm{P} 2,6: \mathrm{P} 3,7$ : hemipenis, $8:$ furca, $9: \mathrm{cp}, 10: \mathrm{A} 1,11: \mathrm{A} 2$. Scales $=0.1 \mathrm{~mm}$.

Figs. 1-11. Leptocythere pseudoproboscidea n.sp., holotype (mâle $0,48 \mathrm{~mm}$ ). 1 : vue dorsale, 2 : valve droite, $3:$ valve gauche, $4: \mathrm{Pl}, 5: \mathrm{P} 2,6$ : P3, $7:$ organe copulateur mâle, $8:$ furca, $9: \mathrm{cp}, 10:$ A1, $11:$ A2. Echelle $=0,1 \mathrm{~mm}$. 


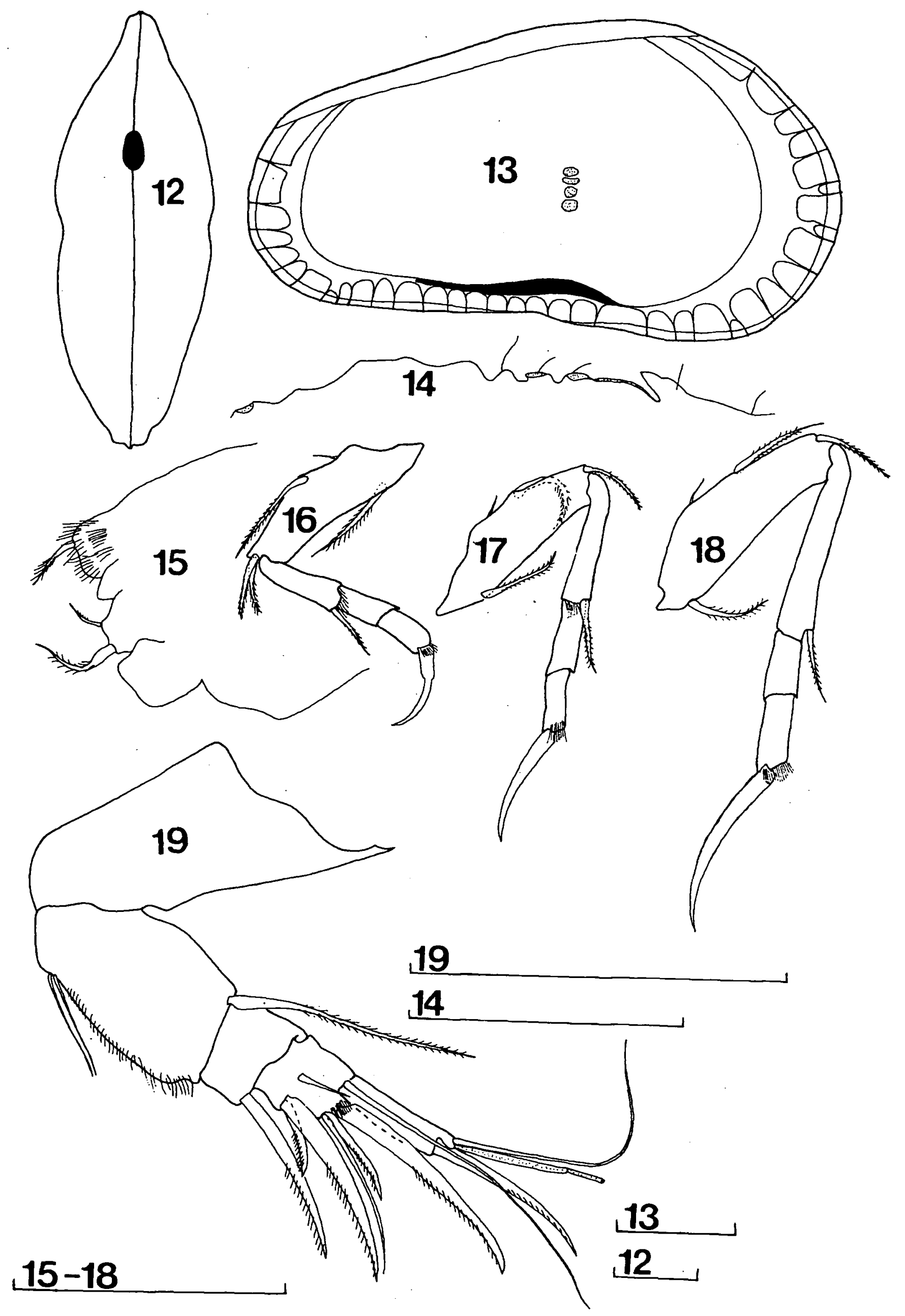

Figs. 12-19. Leptocythere pseudoproboscidea n.sp., allotype (female $0.52 \mathrm{~mm}$ ). 12 : dorsal view, $13:$ left valve, $14:$ appearance of valve surface, $15:$ genital field, $16: \mathrm{P} 1,17: \mathrm{P} 2,18: \mathrm{P} 3,19: \mathrm{A} 1$. Scales $=0.1 \mathrm{~mm}$.

Figs. 12-19. Leptocythere pseudoproboscidea n.sp., allotype (femelle $0,52 \mathrm{~mm}$ ). $12:$ vue dorsale, $13:$ valve gauche, $14:$ ornementation externe de la valve, $15:$ extrémité du corps et furca, $16: \mathrm{P} 1,17: \mathrm{P} 2,18: \mathrm{P} 3,19:$ Al. Echelle $=0,1 \mathrm{~mm}$. 
setae on the second segment reach beyond distal end of terminal segment.

A2 (Fig. 11). Terminal segment with two claws. Penultimate segment is with 3 claws internally and 2 externally. Sensory seta reaches the distal end of penultimate segment. Seta on second segment reaches the distal end of penultimate segment.

Md palp. First segment internally and externally with two setae. Penultimate segment internally with one, externally with two setae. Terminal segment caries 3 claws.

Mx. Without any special characteristics.

P1 (Fig. 4). First segment with 4 setae dorsally, ventrally with one seta. Seta on second segment reaches the distal end of penultimate segment. Terminal claw shorter than the 2 terminal segments combined (75 : 100).

P2 (Fig. 5). First segment with 3 setae dorsally, and 1 seta ventrally. Seta on second segment reaches beyond distal end of penultimate segment. Terminal claw shorter than the 2 distal segments combined (75: 100).

P3 (Fig. 6). First segment with 3 setae dorsally and 1 seta ventrally. Seta on second segment reaches beyond distal end of penultimate segment. Terminal claw longer than the 2 terminal segments combined $(122: 100)$.

Hemipenis (Fig. 7 and 9). Distal lobe (d11) very pointed, d13 weakly developed, but clearly visible, $\mathrm{cp}$ long and pointed distally, and with a clear bump at the base. There are three furcal setae (Fig. 8) : f1 the biggest and the strongest, while setae $\mathrm{f} 2$ and $\mathrm{f} 3$ weakly developed and thin.

\section{FEMALE (Allotype)}

Carapace (Fig. 12-14). Left valve $0.52 \mathrm{~mm}$, right valve $0.51 \mathrm{~mm}$ long. The greatest height lies on the first third of the length, equals $52 \%$ of the length on left valve, and $51 \%$ on the right valve. Seeing from above, posterior end quadriform, anterior beaked. Valves narrow around the middle. The greatest width on the first third, equals $36 \%$ of the length. Dorsal margin straight. Anterior margin wider than posterior. Line of concretion wide with few branched pore canals.

A1 (Fig. 19). Terminal segment 4.2 times as long as width, and $1 / 2$ the length of distal claw on penultimate segment. Length ratio of two proximal claws on penultimate segment $100: 42$, while length ratio of two distal claws $100: 46$.

P1 (Fig. 16). Length ratio of terminal claw and the 2 terminal segments combined $73: 100$.
P2 (Fig. 17). Terminal claw shorter than the 2 terminal segments combined, their length ratio $88: 100$.

P3 (Fig. 18). This leg has terminal claw longer than the 2 terminal segments combined (118:100).

Genital field (Fig. 15). All furcal setae feathery. Furca with short, stout ramus.

A2, Md palp and Mx, as well as arrangement of setae on walking legs same as in male.

\section{Variability}

Length of females varies between $0.49 \mathrm{~mm}$ and $0.52 \mathrm{~mm}$, while length of males varies between $0.43 \mathrm{~mm}$ and $0.48 \mathrm{~mm}$. In both sexes the greatest height ranges between $50 \%$ and $54 \%$ of the length. In females, terminal segment on A1 could be 4.2 times (as it is in allotype female), or 4.5 times as long as width. In females on P1 length ratio of terminal claw and the 2 terminal segments combined, could be $73: 100$ (allotype) or $85: 100$. In males, that ratio could be as in the holotype $75: 100$, or $65: 100$.

\section{Ecology}

Leptocythere pseudoproboscidea n.sp. has been found in autumn and winter in the spring Mareza, in an area where spring floods and makes a little puddle, overgrown with dense vegetation. This puddle never dries up during the year, $w$ hat is very important for the species. Water level varies, with high levels in spring and autumn.

Distribution

The new species is known only from the type locality.

\section{Relationship}

Until now, the genus Leptocythere Sars, 1925 contained 69 recent species (Petkovski \& Keyser 1992). Most of them (91\%) are brackish or marine species, while only $9 \%$ live exclusively in freshwater habitats. Among brackish and marine species Leptocythere pseudoproboscidea $\mathrm{n}$.sp. does not have close relatives. Main differences are in the shape of the carapace, stronger ornaments and different hemipenis (mostly with long d13). Until now, all freshwater species of Leptocythere genus, are known only from Balkan Peninsula. One of the species, Leptocythere ostrovskensis, was described from Lake Vegoritas in Greece (Petkovski \& Keyser 1992). Four species are described from Macedonia. L. proboscidea, $L$. karamani and $L$. angulata are endemic in Ohrid Lake (Klie, 1939), while Leptocythere prespensis was described from Prespa Lake (Petkovski 1959), and latter found in littoral zone of Ohrid Lake (Petkovski \& Keyser 1992). Leptocythere fluviatilis was described from the river Krka in Slo- 
venia (Klie 1939), which is the furthest western point in the Balkan region where species of the genus Leptocythere are found. Leptocythere pseudoproboscidea $\mathrm{n}$. $\mathrm{sp}$. is now the seventh species of the genus found in freshwater habitats of the Balkan Peninsula.

Leptocythere pseudoproboscidea is the most similar to $L$. proboscidea. The following differences can separate these two species:

a) L. pseudoproboscidea is smaller (females 0.49 $0.52 \mathrm{~mm}$; males $0.43-0.48 \mathrm{~mm}$ ) than $L$. proboscidea (females 0.72 - $0.8 \mathrm{~mm}$; males $0.66 \mathrm{~mm}$ ).

b) Seeing from above, females of $L$. proboscidea have two narrowing, while $L$. pseudoproboscidea has only one narrowing. Males of $L$. proboscidea have also wavy carapace in dorsal view, while males of the new species do not posses this characteristic.

c) Terminal segment on A1 in L. proboscidea is 5.4 times as long as width, while in the new species this segment is, at the most, 4.5 times as long as width.

d) In $L$. proboscidea length ratio of two proximal claws on penultimate segment of $A 1$ is $30: 100$, while length ratio of two distal claws is $43: 100$. In females of the new species length ratio of proximal claws is $42: 100$, length ratio of distal claws is 46 : 100 , and in males both pairs of claws have the same ratio - $50: 100$.

e) In L. proboscidea terminal claw on P1 is of the same length as two combined distal segments, or it is slightly longer, while in L. pseudoproboscidea this claw is clearly shorter than two combined distal segments.

f) In contrary to L. proboscidea, which does not posses dl3 on hemipenis, new species has small, but clear d13.

g) In the new species dl1 and cp have very pointed tips, also, cp is with bump in its basal part, while $L$. proboscidea has more rounded tip on $\mathrm{d} 11$ and $\mathrm{cp}$, and there is no basal bump on cp.

All other freshwater Balkan species of the genus Leptocythere differs from the new species in the shape and ornamentation of valves, in the appearance of hemipenis , genital field, and in proportions of length and width of terminal segment on A1, proportions of proximal and distal claws on penultimate segment on $\mathrm{A} 1$, and length ratio of terminal claws and the 2 terminal segments combined on all walking legs.

Accompanying species

In the sample, dated 08 December 1997, together with Leptocythere pseudoproboscidea $\mathrm{n}$. sp., the following species were found : Fabaeformiscandona fabaeformis (Fischer, 1851) (1 female) ; Fabaeformiscando- na brevicornis (Klie, 1925) (3 females) ; Candonopsis mareza Karanovic \& Petkovski (1 male); Cypria lacustris Sars, 1850 (5 females, 1 male and 4 juveniles) and Paralimnocythere karamani (Petkovski, 1960) (10 females, 6 males and 3 juveniles).

In the other sample (25 October 1994) accompanying species were : Cypria lacustris (1 female, $1 \mathrm{ma}-$ le, 1 juvenile) ; Ilyocypris bradyi Sars, 1890 (14 females and 13 juveniles) and Paralimnocythere karamani (26 females, 10 males and 3 juveniles).

\subsection{Paralimnocythere karamani (Petkovski, 1960)} (Figs. 20-25)

\section{Synonymy}

Limnocythere karamani, Petkovski 1960a, p. 58-61, Figs. 1-7 ; Petkovski 1961, p. 8-9, Figs. 9-10 and 1314 ; Petkovski 1969, p. 18, Fig. C/5.

Paralimnocythere karamani, Martens, 1992, p. 145146.

\section{Examined material}

1) Two males and one female from Matica river, near town Podgorica, Skadar Valley, 28 February 1996, collector I. Karanovic.

2) Twenty-six females, ten males and three juveniles from spring Mareza, near town Podgorica, Skadar Valley, 25 October 1994, collector I. Karanovic.

3) Six males, ten females and three juveniles from spring Mareza, 08 December 1997, collector I. Karanovic.

4) Twenty-two females, nine males and two juveniles from spring Mareza, 13 March 1998, collector I. Karanovic.

Two females and three males are dissected. All specimens are deposited in the private collection of the first author, at the Institute of Marine Biology Kotor.

\section{Redescription}

\section{MALE}

Length of the left valve $0.67 \mathrm{~mm}$, right valve $0.65 \mathrm{~mm}$ long. The greatest height lies on the first third, equals on the left valve $45.1 \%$, and on the right $47 \%$ of the length. Dorsal margin straight, posterior margin narrower than anterior. Ventral margin little convex in the middle (Fig. 21). Seeing from above there are two protuberances (Fig. 20). Both anterior and posterior ends pointed. Line of concretion wide on both ends. Valve surface covered with fine dense hairs, and very sculptured. The first antenna (Fig. 26), on the middle of penultimate segment, caries one seta. 


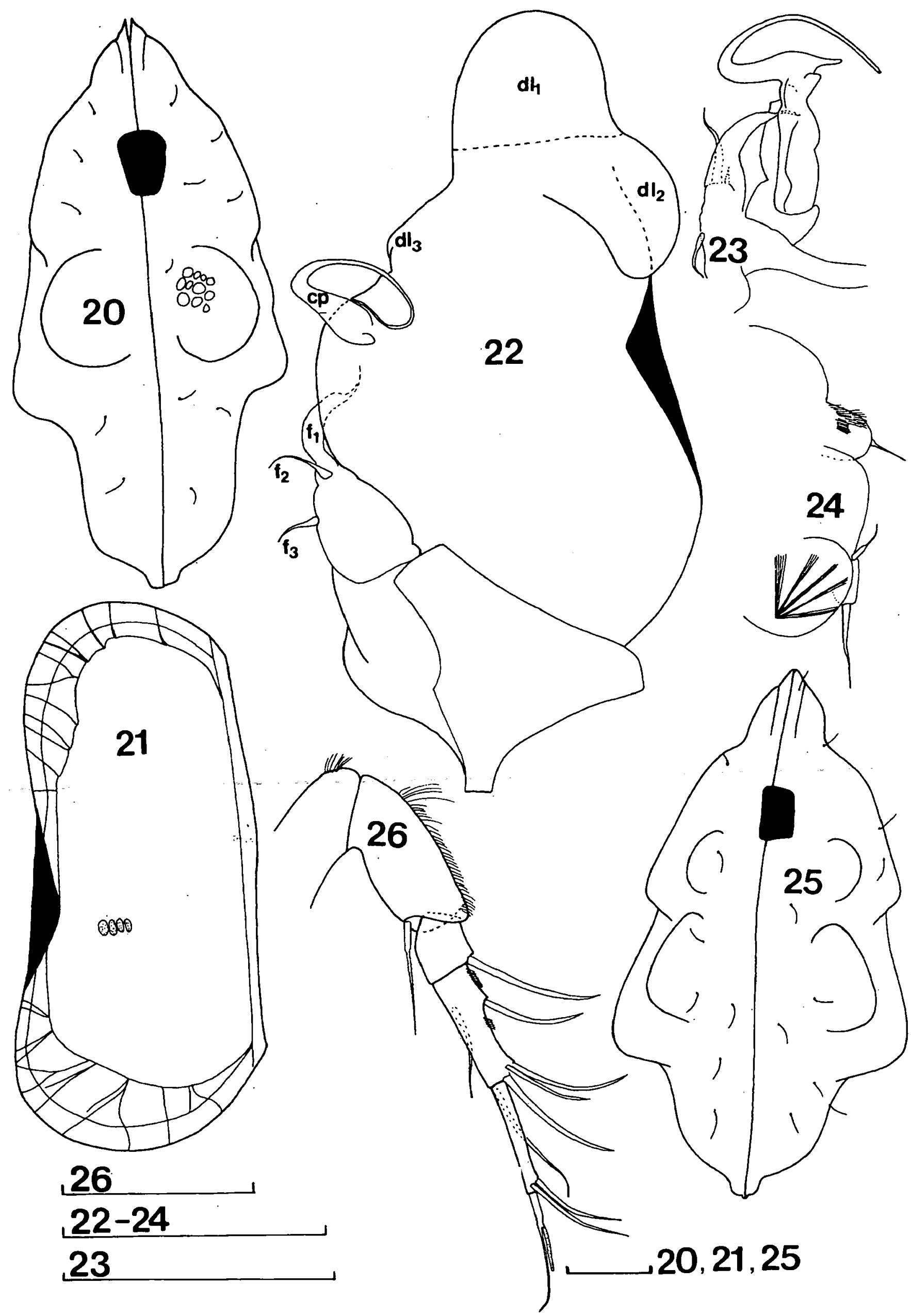

Figs. 20-26. Paralimnocythere karamani (Petkovski 1960). 20-23: male (0.64 mm), 24-26: female (0.63 mm). $20:$ dorsal view, $21:$ left valve, 22 : hemipenis, $23: \mathrm{cp}$ and furca, $24:$ genital field, $25:$ dorsal view, $26:$ A1. Scales $=0.1 \mathrm{~mm}$.

Figs. 20-26. Paralimnocythere karamani (Petkovski 1960). 20-23 mâle (0,64 mm), 24-26: femelle (0,63 mm). 20 : vue dorsale, 21 : valve gauche, 22 : organe copulateur mâle, $23: \mathrm{cp}$ et furca, 24 : extrémité du corps et furca, $25:$ vue dorsale. Echelle $=0,1 \mathrm{~mm}$. 
Length ratios of three distal claws on A2 $100: 80: 52$. Terminal claw on $P 1$ shorter than length of the 2 terminal segments combined, same claw on P2 as long as the 2 terminal segments combined, while distal claw on P3 longer than the 2 terminal segments combined. Hemipenis is of relicta-type, with long flagellum on $\mathrm{cp}$, which is one of the main characteristics of the species (Figs 22-23).

\section{FEMALE}

Left valve $0.65 \mathrm{~mm}$, right valve $0.64 \mathrm{~mm}$ long. On the both valves the greatest height equals $55 \%$ of the length. Females are fatter than males, and the greatest width lies on the last third of the length, equals $58 \%$ of the length (Fig. 25). Apical seta (whip) of furca is longer than furcal ramus (Fig. 24). End of body dull, with one seta in the middle. Other appendages same as in the male.

\section{Variability}

Length of males varies between 0.66 and $0.68 \mathrm{~mm}$, while length of females varies between 0.6 and $0.8 \mathrm{~mm}$. Medial seta on the penultimate segment of A1 may reach till distal end of same segment, or, it could be shorter (till last third of the penultimate segment).

\section{Ecology}

Paralimnocythere karamani is found in littoral zone of lakes (in Macedonia), and in spring and river (in Montenegro). In spring, the species lives, in an area where spring makes little puddle, overgrown with dense vegetation. Adults and juveniles were found in winter as well as in spring.

Distribution

Until now, P. karamani has been found in two Macedonian lakes (Ohrid Lake and Prespa Lake) and in two localities in Skadar Lake drainage area, in Montenegro (spring Mareza and river Matica) (Fig. 27).

\section{Accompanying species}

In the spring Mareza (sample dated 13 March 1998), together with Paralimnocythere karamani, the following species were found : Ilyocypris bradyi Sars, 1890 (6 females and 8 juveniles); Candonopsis kinsleii (Brady \& Robertson 1870) (1 female) ; Pseudocandona lobipes (Hartwig 1900) (1 female) ; Cypridopsis clathrata Klie, 1936 (1 female).

In the second locality, river Matica, together with Leptocythere karamani, the following species were found : Candona candida (Muller, 1776) (1 female); Candona altoides Petkovski, 1961 (1 male, 5 juveniles) and Cypridopsis vidua (Muller, 1776) (1 female).
For the localities 2 and 3, accompanying species are given with the species Leptocythere pseudoproboscidea n.sp.

\section{Zoogeographic analysis}

Ohrid Lake is one of the 7 worlds ancient lakes (Martens 1994, Martens et al. 1994). In most of the ancient lakes ostracods belong to one of the 3 groups : Candonidae, Cytherideinae and Limnocytheridae (Martens 1994). Ohrid Lake has rich ostracod fauna with several endemic species that are representatives of the 3 following families : Candonidae, Limnocytheridae and Leptocytheridae. For now, 46 species are found in Ohrid Lake (Holmes 1937, Klie 1939, 1939a, 1941, Petkovski 1959a, 1960a, 1960b, 1969, 1969a). Among them, there are 20 (43\%) endemic species in Ohrid Lake and $6(13 \%)$ species that are endemic in the Ohrid-Prespa region. In Ohrid Lake there are «palaeoendemics» (relicts) which are survivors of an old continental fauna as well as «neoendemics» : arising from intralacustrine speciation (Martens et al. 1994). In the genus Paralimnocythere Carbonnel, 1965 there are 3 endemic species : P. georgevitschi (Petkovski 1960), P. slavei (Petkovski 1969) and P. umbonata (Klie 1939). Species : P. karamani (Petkovski 1960) and $P$. ohridense (Klie 1939) are endemic in OhridPrespa region because, except in Ohrid, they were also found in Prespa Lake. Genus Leptocythere Sars, 1925 has 3 endemic species in Ohrid Lake : L. proboscidea Klie, 1939, L. karamani Klie, 1939 and L. angulata Klie, 1939, while $L$. prespensis is endemic in OhridPrespa region. Ohrid and Prespa lakes are separated by mountain Galicica and they communicate trough underground waters (Karaman 1971). Among 19 species found in Prespa Lake, only 1 is endemic species and 2 are endemic subspecies (Petkovski 1960, 1960a). Prespa Lake is on the higher altitude than Ohrid (about $158 \mathrm{~m}$ above), and its fauna, although, with few endems, is not so rich as the Ohrid Lake one. This could be explain by the isolation of Prespa Lake that does not have rich surface communication with other drainage areas, and does not possess so many springs in its surrounding. In contrast, Ohrid Lake is unique spring-lake system, which takes water from strong coastal and intralacustrine springs. Also, from Ohrid Lake flows out river Crni Drim, and through this river, lake has strong connection with other drainage areas. One of those connections is the link Ohrid-Drim-Skadar (Fig. 27), which among other connections, enable introduction of species into Ohrid Lake. Those introduced species stay unchanged and only enrich lake's fauna, or they evolve into separate subspecies and species. Im- 


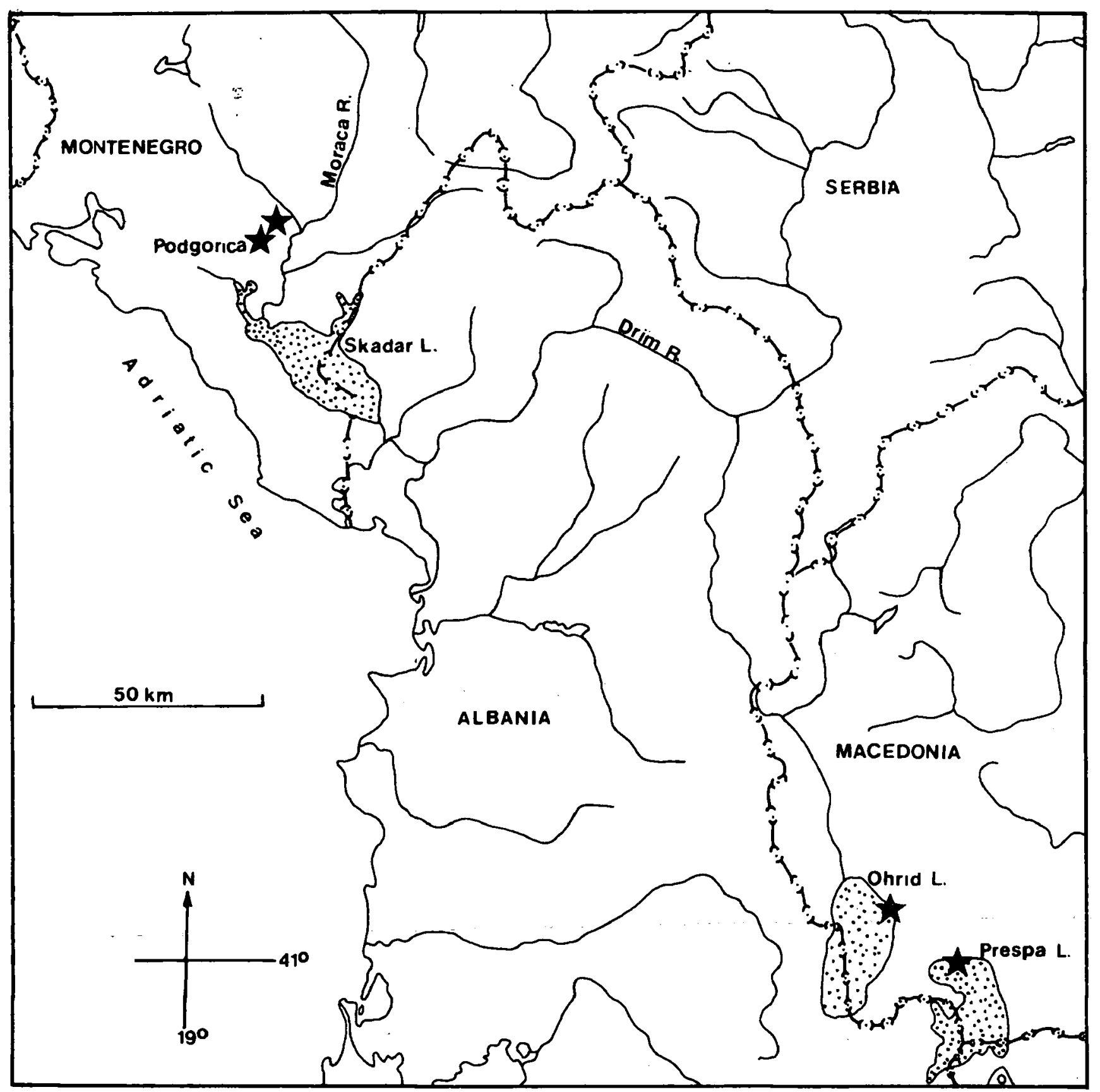

Fig. 27. Distribution of Paralimnocythere karamani (Petkovski 1960).

Fig. 27. Distribution de Paralimnocythere karamani (Petkovski 1960).

portance of this system for Ohrid Lake could be found in fish fauna, where 2 of 3 endemic species have ancestors that came into Ohrid Lake by Drim system and here evolve as separate species. Also, many other representatives of fish fauna came in Ohrid Lake in the same way (Karaman 1971). By system Skadar-DrimOhrid, also, species $P$. karamani distributed, and its ecological adaptation on the lake, river and spring environments, suppose that it could be found in the wide area of Drim, Skadar and Ohrid drainage areas. Species $L$. pseudoproboscidea n.sp. is until now found only in Skadar Valley, but the most similar species, $L$. proboscidea, is endem in Ohrid Lake. Further investi- gations might show that other endemic species from Ohrid Lake live also in Skadar Valley.

Skadar Valley was one of the most important refugial centers in Dinaric region during cyclic periods of the Ice Ages. Rich drainage area as well as good climate conditions gave the refuge to many species. In this valley many of those species evolved and stood here as endems. Fauna of the animal groups that is systematically investigated gives the proofs for this claim. For example, amphipod fauna counts 10 endemic species in Skadar Valley (Karaman 1981). On the other hand, Skadar Lake itself does not posses so many endems. This is certainly linked to its shallow depth (the 
average depth is about $5 \mathrm{~m}$ ) and its very high summer temperature (over $30^{\circ} \mathrm{C}$ ). Eventhough, Skadar Lake has larger surface, it has 26 times less water than Ohrid Lake which is much deeper. This can support great number of ecological niches that enables intralacustrine evolution. In contrast with the Ohrid Lake, species from Skadar Lake easily distributes out of the lake what disable existence of many endems in Skadar Lake. For now, there are only 2 ostracod species found exclusively in Skadar Lake (Petkovski 1961) : Limnocythere scutariense Petkovski, 1961 and Candona montenegrina Petkovski, 1961.

\section{References}

Holmes P.F. 1937. — Ostracoda of Lake Ohrid. Arch. Hydrobiol. 31 (3) : 484-500.

Karanovic I. \& Petkovski T.K. (in press). - Two new species of the subfamily Candoninae (Ostracoda) from Montenegro (SE Europe). Crustaceana.

Karaman G.S. 1981. - Crustacea Decapoda, Mysidacea and Amphipoda from lake Skadar drainage system. In : The Biota and Limnology of Lake Skadar, Karaman G.S. \& Beeton A.M. (eds), Titograd : 246-250.

Karaman M.S. 1971. - Zoogeographische Verhaltnisse des Prespa und Ochridsees. Izdanja, Institut de Pisciculture de la RS de Macédoine, 4 (5) : 1-21.

Klie W. 1936. - Neue Ostracoden aus Jugoslavien. Glasnik Skopskog naucnog drustva, Skopje, 17 : 143-150.

Klie W. 1939. - Studien uber Ostracoden aus dem Ohridsee : II. Limnocytherinae und Cytherinae. Arch. Hydrobiol., 25 : 631- 646.

Klie W. 1939a. - Studien uber Ostracoden aus dem Ohridsee. I Candocyprinae. Arch. Hydrobiol., 35 : 28-45.

Klie W. 1941. - Studien über Ostracoden aus dem Ohridsee : III. Erster Nachtrag. Arch. Hydrobiol., 38 : 254-259.

Martens K. 1990. - Revision of African Limnocythere s.s. Brady, 1867 (Crustacea, Ostracoda), with special reference to the Right Valley Lakes ; morphology, taxonomy, evolution and (palaeo-) ecology. Arch. Hydrobiol., 83 (4) : 453-524.
Martens K. 1992. - A reassessment of Paralimnocythere Carbonnel, 1965 (Crustacea, Ostracoda, Limnocytherinae), with a description of a new genus and two new species. Bull. de L'Inst. Royal des Sci. Nat. de Belgique, 62 : 125-158.

Martens K. 1994. - Ostracod speciation in ancient lakes : a review. Arch. Hydrobiol. Beih. Ergebn. Limnol., 44 : 203-222.

Martens K., Coulter G. \& Godderis B. 1994. - Speciation in Ancient lakes - 40 years after Brooks. Arch. Hydrobiol. Beih. Ergebn. Limnol., 44 : 75-96.

Petkovski T.K. 1959. - Beitrag zur Kenntnis der Ostracoden - Fauna Jugoslawiens (V). Hidrobiologi, Seri B, 4 (4) : 158-165.

Petkovski T.K. 1959a. - Susswasserostracoden aus Jugoslavien VI. Acta Mus. Macedonici Sci. Nat., 6 (3) : 53-75.

Petkovski T.K. 1960. - Zur Kenntnis der Crustaceen des Prespasees. Fragmenta Balcanica, 3 (5) : 117-131.

Petkovski T.K. 1960a. - Zwei neue Ostracoden aus dem Ohrid- und Prespasee. Izdanja, Institute de Pisiculture de la RS de Macedoine, 3 (2) : 57-65.

Petkovski T.K. 1960b. - Süsswasserostracoden aus Jugoslavien VII. Fragmenta Balcanica., 3 (12) : 99-106.

Petkovski T.K. 1961. - Zur Kenntnis der Crustaceen des Skadar(Scutari-) Sees. Acta Mus. Macedonici Sci. Nat., 8 (2) : 29-52.

Petkovski T.K. 1964. - Bemerkenswerte Entomostraken aus Jugoslavien. Acta Mus. Macedonici Sci. Nat., 9 (7) : 143-181.

Petkovski T.K. 1969. — Zwei neue Limnocythere - Arten aus Mazedonien (Crustacea - Ostracoda). Acta Mus. Macedonici Sci. Nat., $12(1): 1-18$.

Petkovski T.K. 1969a. - Einige neue und bemerkenswerte Candoninae aus dem Ohridsee und einige anderen Fundorten in Europa. Acta Mus. Macedonici Sci. Nat., 11 (5) : 81-110.

Petkovski T.K. 1976. Zwei neue und eine seltene Ostracoden-Art der Gattung Cypria Zenker aus Jugoslawien (Nebst einer Bestimmungstabelle der europaischen Arten). Acta Mus. Macedonici Sci. Nat., 14 (7) : 173-192.

Petkovski T.K. \& Keyser D. 1992. - Leptocythere ostrovskensis sp. n. (Crustacea, Ostracoda, Cytheracea) aus dem See Vegoritis (Ostrovsko Ezero) in NW Griechenland. Mitt. hamb. zool. Mus. Inst., 89 : 227-237.

Radulovic V. 1983. - Prilog poznavanju polozaja i velicine sliva Skadarskog Jezera i njegovo hranjenje i praznjenje vodama. In : Skadarsko Jezero, Zbornik Radova sa Simpozijuma, Bozina Ivanovic (ed.), Titograd : 45-56. 